\title{
PENGARUH GAYA KEPEMIMPINAN TRANSFORMASIONAL TERHADAP KEDISIPLINAN PEGAWAI DI KANTOR DINAS KEPENDUDUKAN DAN PENCATATAN SIPIL KABUPATEN TAKALAR
}

\author{
Nur Firman', Nuryanti Mustari², Nurbiah Tahir ${ }^{3}$ \\ Universitas Muhammadiyah Makassar \\ e-mail: nurfirm@gmail.com
}

\begin{abstract}
This study aimed to determine and analyze the influence of transformational leadership style on employee discipline in the Office of Population and Civil Registry of Takalar Regency. This study used a descriptive study using quantitative methods and approaches that described the transformational leadership style of employee discipline in the Office of Population and Civil registry of Takalar Regency. The population in this study were all employees in the Office of Population and Civil Registry of Takalar regency as many as 50 people, civil servants were 30 people and 20 honorary. Sampling technique used saturated sampling. The results showed that the transformational leadership style had a positive and significant effect on employee discipline at the Office of Population and Civil Registration, with an $R$ square coefficient of 0,524, meaning $52.4 \%$ of the leadership style affected employee discipline at the Office of Population and Civil Registration at Takalar Regency.
\end{abstract}

Keywords: Transformational Leadership Style, Employee Discipline

\begin{abstract}
Abstrak
Penelitian ini bertujuan untuk mengetahui dan menganalisis pengaruh gaya kepemimpinan transformasional terhadap kedisiplinan pegawai di Kantor Dinas Kependudukan dan Pencatatan Sipil Kabupaten Takalar. Jenis penelitian yang digunakan adalah penelitian deskriptif dengan menggunakan metode dan pendekatan kuantitatif yang menggambarkan gaya kepemimpinan transformasional terhadap kedisiplinan pegawai di Kantor Dinas Kependudukan dan Pencatatan Sipil Kabupaten Takkalar. Jumlah populasi dalam penelitian ini adalah seluruh pegawai di Kantor Dinas Kependudukan dan Pencatatan Sipil Kabupaten Takalar sebanyak 50 orang, PNS 30 dan 20 honorer. Penarikan sampel dalam penelitian menggunakan sampling jenuh. Hasil penelitian menunjukkan bahwa gaya kepemimpinan transformasional berpengaruh positif dan signifikan terhadap kedisiplinan pegawai di Kantor Dinas Kependudukan dan Pencatatan Sipil, dengan nilai koefisien R square sebesar 0,524 artinya 52,4\% gaya kepemimpinan mempengaruhi kedisiplinan pegawai di Kantor Dinas Kependudukan dan Pencatatan Sipil Kabupaten Takalar.
\end{abstract}

Kata Kunci: Gaya Kepemimpinan Transformasional, Kedisiplinan Pegawai

\section{PENDAhUluan}

Kepemimpinan ialah inti dari sebuah organisasi dan manajemen.Kepemimpinan mempunyai peran menentukan kegagalan dan keberhasilan organisasi dalam usaha untuk mencapai tujuan yang menjadi cita-cita bersama. Kepemimpinan merupakan peranan yang sangat penting dalam pengawasan dan penegakan kedisiplinan dalam sebuah organisasi. Kepemimpinan adalah proses di mana seseorang atau sekelompok orang memainkan pengaruh atas orang lain untuk mencapai sasaran atau tujuan. Kepemimpinan merupakan kemampuan positif yang dimiliki seseorang untuk mempengaruhi orang lain dan sebagai sistem untuk memberikan suatau dampak yang berguna untuk mencapai hasil yang optimal. Ali, (2012:67). 
Peraturan Pemerintah Republik Indonesia mengenai disiplin pegawai antara lain memuat tentang kewajiban serta larangan dan hubungan disiplin untuk dapat dijatuhi sanksi kepada pegawai yang telah terbukti melanggar peratauran guna untuk embina pegawai, agar pegawai yang terindikasi melakukan pelanggaran menyesali dan berusaha untuk tidak mengulangi kesalahan dan mampu memperbaiki diri dimasa yang akan datang. . Menumbuhkan sikap disiplin pegawai tentang Pasal 30 Undang-Undang Nomor 53 Tahun 2010 tentang peraturan disiplin pegawai

Gaya kepemimpinan transformasional ialah salah satu model kepemimpinan yang bertujuan mentrasformasikan nilai-niali yang dipercaya oleh bawahan guna untuk mendukung visi dan misi organisasi.Dengan trasformasi nilai-nilai tersebut dapat memberikan manfaat sehingga terjalin hubungan yang baik antara anggota serta rasa saling percaya sebagaimana yang diharapkan dalam sebuah organisasi. Kepemimpinan transformasional inilah yang diartikan sebagai kepemimpinan yang sebenarnya dikarena kepemimpinan ini bekerja untuk mencapai sasaran pada perilaku yang mengarahkan organisasi kepada suatu orientasi yang ingin dicapai. Selain itu, kepemimpinan transformasional merupakan gambaran yang terbaik dalam menguraikan ciri-ciri kepemimpinan sehingga para pemimpin kita lebih berkerakyatan dan berkeadilan sosial.Sarros dalam Ali, (2013:108). Sedangkan kedisiplinan pegawai merupakan fungsi operatif memperdayakan sumber daya manusia (MSDM) sangat penting karena semankin membaiknya kedisiplinan pegawai akan mempengaruhi performa pekerjaan yang bakal dicapai. Tanpa sifat kedisiplinan yang tinggi dalam diri pegawai dalam suatu organisasiakan sulit bagi organisasi tersebut mencapai hasil yang dinginkan.Malayu Hasibuan dalam Purnamasari, (2015:3).

Gaya Kepemimpinan yang ditampilkan seorang pemimpin dapat mempengaruhi sikap, perilaku dan disiplin para pegawainya.Gaya kepemimpinan transformasional mungkin dapat berpengaruh positif terhadap kedisiplinan kerja para pegawai. Kedisiplinan merupakan sikap positif para pegawai yang mampu mendorong pegawai dapat bekerja lebih baik, namun sejauh ini kebanyakan seorang pemimpin kurang memperhatikan para pegawai seperti yang terjadi di Kantor Dinas Kependudukan Dan Pencatatan Sipil Kabupaten Takalar yang dimana bawahannya masih banyak melakukan pelanggaran seperti halnya berpakaian tidak sesuai dengan peraturan, adanya pegawai mengacuhkan pekerjaanya dan lebih memilih dikantin kantor dinas dengan bersantai-santai, merokok, dan mengobrol dibandingkan mengerjakan tugasnya, banyak pegawai yang datang terlambat dan pulang tidak tepat pada waktunya.

Berdasarkan observasi awal pada Kantor Dinas Kependudukan dan Pencatatan Sipil Kabupaten Takalar, peneliti melihat bahwa gaya kepemimpinan yang diterapakan Kepala Dinas Kependudukan dan Pencatatan Sipil Kabupaten Takalar belum terlalu maksimal atau optimalartinya belum terlihat adanya pengaruh terhadap kedisiplinan pegawai karena masih banyak pegawai yang sering melakukan pelanggaran padahal kita ketahui bahwa kepemimpinan transformasional adalah kepemimpinan yang sangat baik dalam melakukan pendekatan serta kerjasa sama terhadap bawahahnnya karena pemimpin yang transformasional lebih beriorientasi kepada karyawan atau bawahan seperti halnya dimana seorang pemimpin melibatkan bawahannya dalam pengambilan keputusan, pemimpin lebih bersifat kekeluargaan, saling percaya, kerja sama dan saling menghormati diantara sesama anggota kelompok. Namun dilihat dari gaya kepemimpinan kepala dinas kependudukan dan pencatatan sipil kabupaten takalar belum mampu mengoptimalkan gaya kepemimpinannya dalam malakukan controling terhadap kedisiplinan bawahannya yang melakukan pelanggaran padahal seharusnya seorang pemimpinlah yang harus mengontrol dan memotivasi bawahannya agar disiplin dalam bekerja karna seorang pemimpinlah yang harus menjadi tauladan dari para bawahannya agar bisa disiplin dalam bekerja.

Dalam gaya kepemimpinan transformasional yang ada di Dinas Kependudukan dan Pencatatan Sipil Kabupaten Takalar menerapkan gaya kepemimpinan transformasional yang belum maksimal atau optimal, artinya kepemimpinan yang belum mampu untuk memberikan suatu motivasi yang akan menginspirasi para bawahannya. Sedangkan kedisiplinan 
merupakan hal berpengaruh yang mesti dimiliki oleh setiap pegawai dalam mengaktualisasikan semua potensinya dalam dunia kerja, namun yang terjadi dikepemimpinan Kepala Dinas Kependudukan dan Pencatatan Sipil di Kabupaten Takalar belum mampu mengoptimalkan gaya kepemimpinannya dalam malakukan kontroling terhadap kedisiplinan bawahannya yang melakukan pelanggaran seperti halnya pegawai yang datang kekantor jam 07.00 pagi untuk melakukan check lock namun belum menggunakan atribut kedinasan, paska melakukan check lock pegawai langsung meninggalkan kantor dan datang ke kantor pukul 09.00, padahal sesuai aturan disiplin pegawai jam 07.30 pegawai sudah harus ada di kantor dan melakukan rutinitas pegawai seperti biasanya, masih ada beberapa pegawai yang mengacuhkan pekerjaannya dan lebih memilih mengobrol dibandingkan menyelesaikan tugasnya, dan selain itu juga masih ada beberapa pegawai yang datang terlambat dan pulang tidak tepat pada waktunya.

Dalam penelitian ini Gaya Kepemimpinan Transformasional terhadap Kedisiplinan Pegawai merupakan hal yang menarik untuk diteliti karena gaya kepemimpinan transformasional memberikan pengaruh terhadap kedisiplinan kerja para pegawai, maka seorang pemimpin akan lebih diyakini keberhasilannya mendorong perubahan suatu organisasi.

Kepemimpinan adalah suatu cara atau bentuk untuk mempengarahi dan perilaku untuk memenangkan hati, pikiran, dan tingkah laku orang lain. Namun pada umumnya defenisi mengenai kepemimpinan selalu dikaitkan dengan suatu metode atau proses dimana seseorang diarahkan dalam mencapai sasaran yang telah disepakati bersama. Artinya bentuk kepemimpinan ini menekankan pada proses dimana seorang pemimpin berperang penting atas bawahannya guna mengarahkan pekerjaan mereka dalam mencapai tujuan yang telah ditetapkan. Setiawan, (2013:13).

Menurut Viethzal Rivai dan Deddy Mulyadi (2011:2), Mengemukakan bahwa: "Kepemimpinan merupakan suatu keadaan untuk mengarahkan dan mempengaruhi perilaku yang berhubungan dengan pekerjaan para anggota kelompok"
Menurut Yulk (2009:8), mengemukakan bahwa : "kepemimpinan merupakan proses memberikan pengaruh terhadap orang lain agar dapat memahami dan setuju dengan apa yang mesti dilakukan agar tugas dapat berjalan secara efektif, serta keadaan untuk memberikan fasilitas berupa upaya-upaya individu dan koleratif untuk mencapai tujuan bersama".

Kepemimpinan transformasional terdiri dari dua kata yaitu kepemimpinan dan transformasional, kepemimpinan adalah gaya atau cara yang digunakan pemimpin dalam mempengaruhi pengikut atau bawahannya dalam melakukan kerjasama untuk mencapai tujuan yang telah ditentukan. Sedangkan transformasional mengubah suatu hal menjadi bentuk lain. Jadi kepemimpinan transformasional adalah merubah pengikut yang dipimpin kearah pengembangan organisasi. Pasolong, (2010:128).

Menurut Briyan (2014:5), Kepemimpinan transformasional memberikan perhatian kepada hal-hal dan kebutuhan untuk mengembangkan masing-masing pengikutnya. Pemimpin transformasional mengubah pola pikir pengikutnya agar timbul kesadaran akan persoalan-persoalan dengan membantu mereka dengan cara memberikan pandangan untuk memandang masalah lama dengan cara-cara baru, dan mereka mampu memberikan sugesti kepada para pengikut guna membangkitkan gairah dan mengilhami para pengikut untuk berupaya ekstra demi mencapai sasaran kelompok.

Sedangkan menurut Peter (2013:176), mengemukakan bahwa : "kepemimpinan transformasional merupakan proses dimana sesorang terlibat dengan orang lain dan menciptakan hubungan yang meningkatkan motivasi dan moralitas dalam diri pemimpin dan bawahan. Jenis pemimpin ini memiliki perhatian pada kebutuhan dan motif pengikut serta mencoba membantu pengikut mencapai potensi terbaik mereka"

Kedisiplinan adalah kesadaran dan kesediaan diri seseorang untuk tidak melakukan pelanggaran dan mentaati semua peraturan dan norma-norma sosial yang berlaku didalam sebuah organisasi. Selain itu kesadaran juga diartikan sebagai sikap menaati semua peraturan dan sadar akan tanggung jawabnya dan bukan atas dasar paksaan. Hasibuan dalam Ananto, (2014:31). 


\section{METODE PENELITIAN}

Penelitian ini menggunakan jenis penelitian kuantitatif dengan tipe penelitan deskriptif. Populasi dalam penelitian ini adalah pegawai di Kantor Dinas Kependudukan dan Pencatatan Sipil Kabupaten Takalar sebanyak 50 orang, PNS 30 dan 20 honorer. Teknik penentuan pengambilan sampel menggunakan teknik sampling jenuh.

Teknik pengumpulan data yang dipilih adalah dengan menggunakan kuesioner (angket) menggunakan bentuk checklist. Peneliti akan melakukan uji validitas dengan menggunakan bantuan software SPSS version 24.0. Pengujian validitas cukup dengan membandingkan nilai $r_{\text {hitung }}$ dengan nilai $r_{\text {tabel }}$ Product Moment.Jika nilai $r_{\text {hitung }} \geq r_{\text {tabel }}$ maka indikator atau pertanyaan kuesioner dikatakan valid, begitupula sebaliknya.Data juga dikatakan valid jika nilai sig. (2-tailed) data $<0.05$, dan akan melakukan Pengujian realibilitas cukup dengan membandingkanr ${ }_{\text {alpha }}$ atauangka cronbach alpha dengan nilai 0,7.Jikar ${ }_{\text {alpha }}$ atau angka cronbach alpha $\geq 0,7$ maka indikator atau pertanyaan kuesioner dikatakan reliabel,begitupula sebaliknya.

Teknik analisis data yang digunakan yaitu, teknik analisis statistik deskriptif yang akan digunakan dalam penelitian ini berupa tabel, perhitungan modus, median, mean (pengukuran tendensi sentral), perhitungan penyebaran data melalui perhitungan rata-rata dan standar deviasi, serta perhitungan persentase $(\%)$.

Teknik pengabsahan data Untuk mengukur data,ada dua konsep yang digunakan yaitu validitas dan reliabilitas. Suatu penelitian akan menghasilkan kesimpulan yang bias datanya kurang valid dan kurang reliable. Uji validasi dimaksudkan untuk mengetahui validasi instrumen/kuesioner. Menurut Sugiono (2014:121) "hasil penelitian yang valid bila terdapat kesamaan antara data yang terkumpul dengan data yang sesungguhnya terjadi pada obyek yang diteliti". Teknik yang digunakan yaitu korelasi Pearson Product Moment,yaitu cara melakukan korelasi masing-masing variabel dengan skor totalnya. Suatu variabel/pertanyaan dikatakan valid bila skor variabel/pertanyaan tersebut berkorelasi secara signifikan dengan skor total. Uji realibilitas di lakukan dengan maksud untuk mengetahui tingkat konsistensi terhadap instrumeninstrumen yang mengukur konsep. Realibilitas merupakan syarat untuk tercapainya validitas kusioner dengan tujuan penelitian. Teknik pengujian realibilitas yang dilakukan yaitu dengan menggunakan nilai Cronbach's Alpa.

\section{HASIL DAN PEMBAHASAN}

Data ini diperoleh melalui kuesioner yang didistribusikan kepada 50 pegawai di Kantor Dinas Kependudukan dan Pencatatan Sipil. Kuesioner yang dibagikan terdiri dari dua variabel. Variabel $\mathrm{X}$ yaitu untuk mengetahui pengaruh gaya kepemimpinan transformasional dan variabel $\mathrm{Y}$ yaitu untuk mengetahui kedisiplinan pegawai yang diberikan di Kantor Dinas Kependuduksn dan Pencatatan Sipil. Penyajian data meliputi datadata tentang identitas dan distribusi jawaban responden di Kantor Dinas Kependudukan dan Pencatatan Sipil terhadap pertanyaan ataupun pernyataan yang diajukan dan diuraikan dalam tabel frekuensi yaitu, deskriptif data identitas responden.

\section{Responden PNS}

Berdasarkan hasil analisis yakni deskripsi identitas responden berdasarkan jenis kelamin, menunjukan bahwa responden yang berjenis kelamin laki-laki sebesar 12 orang atau $40 \%$ dan berjenis kelamin perempuan sebesar 18 orang atau $60 \%$. Dari angka tersebut menggambarkan bahwa PNS yang berjenis kelamin perempuan lebih banyak yakni 18 orang atau $60 \%$ dan sisanya adalah responden dengan berjenis kelamin laki-laki sebanyak 12 orang atau $40 \%$ dengan total responden $100 \%$.

Berdasarkan hasil analisis, PNS yang paling banyak adalah PNS yang berada pada umur diatas 48 tahun yaitu sebanyak 14 orang (46,6\%), kemudian kelompok umur 36-41 tahun yaitu sebanyak 8 orang $(26,7 \%)$, kemudian kelompok umur 42-47 tahun yaitu sebanyak 5 orang $(16,7 \%)$, kemudian kelompok umur yang paling sedikit berada pada kelompok umur 30-35 tahun yaitu sebanyak 3 orang (10\%).

Berdasarkan hasil analisis dapat dilihat bahwa PNS di dinas kependudukan dan pencatatan sipil kabupaten takalar mayoritas 
berada pada golongan IIIa - IIId yaitu sebanyak 18 orang $(60 \%)$, kemudian golongan IIa-IId dan golongan IVa-IVd masing-masing berjumlah 6 orang (20\%). Kemudian dari tabel tersebut kita juga dapat melihat bahwa tidak ada PNS dengan golongan Ia-Id yang menjadi responden dalam penenelitian ini.

\section{Responden Pegawai Honorer}

Berdasarkan hasil analisi dapat dilihat bahwa dari seluruh responden pegawai honorer yang berjumlah 20 orang, jumlah responden yang lebih banyak adalah yang berjenis kelamin perempuan yaitu sebanyak 17 orang $(85 \%)$ jauh berbeda dengan responden laki-laki yang cumanberjumlah3 orang (15\%).

Hasil analisis dapat kita ketahui bahwa jumlah responden terbanyak berada kelompok umur 30-35 tahun yang berjumlah 16 orang (80\%), kemudian diikuti oleh kelompok umur 36-41 tahun sebanyak 2 orang (10\%),dankelompok umur 42-47 tahun dan diatas 48 tahun yang masing-masing berjumlah 1 orang $(5 \%)$.

Hasil analisis menunjukkan bahwa responden paling banyak yaitu dengan tingkat pendidikan Sarjana sebanyak 12 orang (60\%), kemudian responden dengan tingkat pendidikan SMA/Sederajat sebanyak 6 orang $(30 \%)$, dan responden dengan tingkat pendidikan Diploma sebanyak 2 orang (10\%), Dari tabel tersebut kita dapat melihat bahwa tidak ada pegawai honorer dengan tingkat pendidikan Pascasarjana yang menjadi responden dalam penelitian ini.

Setelah keseluruhan data yang diperoleh pada saat peneitian dari hasil kuesioner disimpulkan, maka tahap selanjutnya yaitu melakukan analisis data variabel $\mathrm{X}$ "Pengaruh Gaya Kepemimpinana Transformasional" dan juga menjawab pertanyaan dari rumusan msalah pertama penelti yaitu untuk mengetahui bagaimana gaya kepemimpinan transformasional di Kantor Dinas Kependudukan dan Pencatatan Sipil Kabupaten Takalar. Adapun indikator gaya kepemimpinan transformasional yaitu sebagai berikut :

Kharisma: memberikan visi dan rasa misi, menanamkan kebanggaan, meraih penghormatan dan kepercayaan. Artinya seorang pemimpin yang transformasional harus memiliki kharisma, kemampuan, keahlian visi, dan tindakan dalam menginspirasi bawahannya untuk melakukan inovasi dan perubahan cara kerja.. Dalam indikator kharisma ini adalah bagian dari variabel gaya kepemimpinan transformasional di Dinas Kependudukan dan Pencatatan Sipil Kabupaten Takalar, maka dari itu untuk mengetahui indikator kharisma diukur melalui sub indikator dalam 5 Pernyataan. Berdasarkan hasil analisis maka indikator Kharisma dengan lima item pernyataan penilaian rata-rata dari 50 responden yaitu $30,8 \%$ responden yang memberikan penilaian sangat setuju (SS), 59,6\% responden yang memberikan penilaian setuju (S), 8\% responden yang memberikan penilaian kurang setuju (KS), dan 1,6\% responden yang memberikan penilaian tidak setuju (TS), dan $0 \%$ responden yang memberikan penilaian sangat tidak setuju (STS) terhadap indikator Kharisma divariabel X (Gaya Kepemimpinan Transformasional).

Hasil analisis deskriptif tentang indikator kharisma dapat dilihat bahwa penilaian ratarata responden paling tinggi yakni penilaian setuju yaitu sebesar 59,6\% , sedangkan penilaian rata-rata responden paling rendah yakni penilaian rahu-ragu yaitu sebesar 1,6\% . Gaya kepemimpinan transformasional di Kantor Dinas Kependudukan dan Pencatatan Sipil Kabupaten Takalar dalam menjalankan tugasnya untuk meningkatkan kedisiplinan terhadap pegawainya menunjukkan bahwa memiliki penilaian sangat baik yaitu sebesar $90,4 \%$ responden, penilaian tersebut diperoleh dari hasil analisis indikator kharisma sebesar $59,6 \%$ responden setuju dijumlah dengan $30,8 \%$ responden sangat setuju. Namun dengan begitu masih ada beberapa responden yang memberikan penilaian tidak baik yaitu 9,6\% responden yang diperoleh dari peniliaian $8 \%$ ragu-ragu dijumlah $1,6 \%$ responden tidak setuju. Berdasarkan hasil penilaian tersebut menunjukkan bahwa indikator kharisma berada pada tingkat penilaian sangat baik dengan perolehan hasil sebesar 90,4\%

Inspirasi mengkomunikasikan harapan tinggi, menggunakan simbol untuk memfokuskan pada usaha, menggambarkan maksud penting secara sederhana. Artinya seorang pemimpin yang transformasional tidak dapat memimpin bawahannya apabila ia tidak 
memotivasi dan memberikan inspirasi tentang apa dan bagaimana melakkan tugas/pekerjan. Dalam indikator Inspirasi ini adalah bagian dari variabel gaya kepemimpinan transformasional di Dinas Kependudukan dan Pencatatan Sipil Kabupaten Takalar, maka dari itu untuk mengetahui indikator Inspirasi diukur melalui sub indikator dalam 5 Pernyataan. Hasil analisis deskriptif tengtang indikator inspirasi dapat dilihat bahwa penilaian rata-rata responden paling tinggi yaitu $64,4 \%$ responden memberikan penilaian setuju sedangkan penilaian responden paling rendah yakni $0,4 \%$ yang memberikan penilaian tidak setuju. Gaya kepemimpinan transformasional di Kantor Dinas Kependudukan dan Pencatatan Sipil Kabupaten Takalar dalam menjalankan tugasnya untuk meningkatkan kedisiplinan terhadap pegawainya menunjukkan bahwa memiliki penilaian sangat baik terhadap indikator inspirasi yaitu sebesar $87,6 \%$ responden, penilaian tersebut diperoleh dari hasil analisis indikator inspirasi sebesar 64,4\% responden setuju dijumlah $23,2 \%$ responden sangat setuju. Namun dengan begitu masih ada beberapa responden yang memberikan penilaian tidak baik yaitu sebesar $12,4 \%$ responden diperoleh dari penilaian $12 \%$ raguragu dijumlah $0,4 \%$ responden tidak setuju. Berdasarkan hasil penelitian tersebut menunjukkan bahwa indikator inspirasi berada pada tingkat penilaian sangat baik dengan perolehan hasil sebesar $87,6 \%$.

Stimulasi intelektual mendorong intelegensi, rasionalitas, dan pemecahan masalah secara hati-hati. Artinya pemimpin yang transformasional harus mendorong bawahannya untuk memikirkan kembali cara kerja mereka dan untuk mencari cara-cara baru dalam melaksanakan tugas mereka. Dalam indikator Stimulasi Intelektual ini adalah bagian dari variabel gaya kepemimpinan transformasional di Dinas Kependudukan dan Pencatatan Sipil Kabupaten Takalar, maka dari itu untuk mengetahui indikator Stimulasi Intelektual diukur melalui sub indikator dalam 5 Pernyataan. Hasil deskriptif tentang indikator stimulasi intelektual dapat dilihat bahwa penilaian rata-rata responden paling tinggi yakni $59,2 \%$ responden memberikan penilaian setuju, sedangkan penilaian rata-rata responden paling rendah yakni 7,6\% responden penilaian tidak setuju. Gaya kepemimpinan transformasional di Kantor Dinas Kependudukan dan Pencatatan Sipil Kabupaten Takalar dalam menjalankan tugasnya untuk meningkatkan kedisiplinan terhadap pegawainya menunjukkan bahwa memiliki penilaian sangat baik terhadap indikator stimulasi intelektual sebesar 92,4\% responden, penilaian tersebut diperoleh dari hasil analisis indikator stimulasi intelektual sebesar 59,2\% responden setuju dijumlah dengan $33,2 \%$ responden sangat setuju. Namun dengan demikian masih ada beberapa responden yang memberikan penilaian tidak baik yaitu sebesar $7,6 \%$ responden yang diperoleh dari penilaian sebesar 7,6\% responden ragu-ragu. Berdasarkan hasil penilitian tersebut menunjukkan bahwa indikator stimulasi intelektual berada pada tingkat penilaian sangat baik.

Pertimbangan individual memberikan perhatian pribadi, melayani pegawai secara pribadi, melati dan menasehati. Artinya pemimpin yang transformasional harus memberikan perhatian dan sikap peduli kepada bawahannya. Mengidentifikasi kebutuhan para bawahannya, berusaha sekuat tenaga mengenali kemampuan karyawan dan selalu mendengar bawahannya dengan penuh perhatian.Dalam indikator Pertimbangan Individual ini adalah bagian dari variabel gaya kepemimpinan transformasional di Dinas Kependudukan dan Pencatatan Sipil Kabupaten Takalar, maka dari itu untuk mengetahui indikator Pertimbangan Individual diukur melalui sub indikator dalam 5 Pernyataan. Berdasarkan data tabel diatas maka indikator Pertimbangan Individual dengan lima item pernyataan penilaian ratarata dari 50 responden yaitu $24 \%$ responden yang memberikan penilaian sangat setuju (SS), $63,2 \%$ responden yang memberikan penilaian setuju (S), 11,2\% responden yang memberikan penilaian kurang setuju (KS), 1,6\% responden yang memberikan penilaian tidak setuju (TS), dan $0 \%$ respondenyang memberikan penilaian sangat tidak setuju (STS) terhadap indikator Pertimbangan individual divariabel X (Gaya Kepemimpinan Transformasional).

Hasil deskriptif tentang indikator pertimbanagan individual dapat dilihat bahwa penilaian rata-rata responden paling tinggi yakni $63,2 \%$ responden memberikan penilaian setuju, sedangkan penilaian rata-rata responden paling rendah yakni 1,6\% 
responden penilaian tidak setuju. Gaya kepemimpinana transformasional di kantor Dinas Kependudukan dan Pencatatan Sipil Kabupaten Takalar dalam menjalankan tugasnya untuk meningkatkan kedisiplinan terhadap pegawainya menunjukkan bahwa memiliki penilaian sangat baik terhadap indikator pertimbangan individual sebesar $86,6 \%$ responden, penilaian tersebut diperoleh dari hasil analisis indikator pertimbangan individual sebesar $63,2 \%$ responden setuju dijumlah dengan $23,4 \%$ responden sangat setuju. Namun dengan begitu masih ada beberapa responden yang membarikan penilaian tidak baik yaitu sebesar 12,8\% responden yang diperoleh dari penilaian sebesar $11,2 \%$ responden ragu-ragu dijumlah dengan $1,6 \%$ responden tidak setuju. Berdasarkan hasil penilitian tersebut menunjukkan bahwa indikator pertimbangan individual berada pada tingkat penilaian sangat baik dengan perolehan hasil sebesar 86,6\%. Berdasarkan hasil penelitian di Kantor Dinas Kependudukan dan Pencatatan Sipil Kabupaten Takalar mendapatkan hasil sebesar $83,26 \%$ yang menunjukkan bahwa pelaksanaan responden pada variabel $\mathrm{X}$ "Gaya Kepemimpinan Transformasional" berada pada penilaian sangat baik. Menurut pengamatan peneliti, hal tersebut menunjukkan bahwa gaya kepemimpinan transformasional di Kantor Dinas Kependudukan dan Pencatatan Sipil kabupaten Takalar dalam menjalankan kepemimpinannya sudah termasuk sangat baik dari perolehan nilai sebesar $83,26 \%$. Dengan hasil yang diperoleh pada variabel $X$ hal tersebut menggambarkan bahwa gaya kepemimpinan transformasional sudah berjalan sesuai dengan tujuan Kantor Dinas Kependudukan dan Pencatatan Sipil Kabupaten Takalar, hal tersebut dibuktikan pada tanggapan responden terhadap kuesioner yang dibagikan dan pada saat peneliti berada dilapangan dan melihat langsung keadaan pegawai dalam disiplin dan menjalankan tugasnya.

Kedisiplinan adalah kesadaran dan kesediaan diri seseorang untuk tidak melakukan pelanggaran dan mentaati semua peraturan dan norma-norma sosial yang berlaku didalam sebuah organisasi.. Hal tersebut dapat dilihat pengaruhnya dari hasil kuesioner peneliti pada variabel Y “ Kedisiplinan Pegawai" yaitu untuk mengukur sejauh mana peningkatan kedisiplinan pegawai di Kantor Dinas Kependudukan dan Pencatatan Sipil Kabupaten Takalar. Adapun indikator kedisiplinan pegawai yaitu sebagai berikut :

Kehadiran Hal ini merupakan penanda yang mendasar untuk mengukur tingkat kedisiplinan, dan biasanya pegawai yang memiliki tingkat displin kerja yang tinggi cenderung terbisa tepat waktu dalam bekerja..Kehadiran dalam penelitian ini adalah bagian dari indikator dalam variabel Kedisiplinan Pegawai di Kantor Dinas Kependudukan dan pencatatan Sipil Kabupaten Takalar. Maka untuk mengetahui indikator kehadiran diukur melalui sub indikator dalam lima pernyataan. Berdasarkan data tabel diatas maka indikator kehadiran dengan lima item pernyataan penilaian ratarata dari 50 responden yaitu $36,4 \%$ responden yang memberikan penilaian sangat setuju (SS), $56,4 \%$ responden yang memberikan penilaian setuju (S), 6,8\% responden yang memberikan penilaian kurang setuju (KS), 0,4\% responden yang memberikan penilaian tidak setuju (TS), dan $0 \%$ responden yang memberikan penilaian sangat tidak setuju (STS) terhadap indikator kehadiran divariabel Y(Kedisiplinan Pegawai).

Hasil analisis deskriptif tentang indikator kehadiran dapat dilihat bahwa penilaian ratarata responden paling tinggi adalah 56,4\% responden memberikan penilaian setuju, sedangkan penilaian rata-rata responden paling rendah adalah $0,4 \%$ responden memberikan penilaian tidak setuju. Indikator kehadiran di Kantor Dinas Kependudukan dan Pencatatan Sipil Kabupaten Takalar menunjukkan bahwa memiliki penilaian sangat baik yaitu sebesar 92,8\% responden, penilaian tersebut diperoleh dari hasil analisis indikator kehadiran sebesar $56,4 \%$ responden setuju dijumlah dengan $36,4 \%$ responden sangat setuju. Namun dengan begitu masih ada beberapa responden yang memberikan penilaian tidak baik sebesar $7,2 \%$ responden yang diperoleh dari penilaian sebesar $6,8 \%$ responden ragu-ragu dijumlah dengan $0,4 \%$ responden tidak setuju.

Hasil penelitian diatas merupakan hasil observasi peneliti dilapangan, bahwa kedisiplinan pegawai di kantor dinas kependudukan dan pencatatan sipil kabupaten takalar pada indikator kehadiran yaitu dengan melihat aktivitas yang dilakukan akan diselesaikan dengan baik, sehingga akan 
memberikan keuntungan pada instansi dan mendapatkan tanggapan yang sangat baik dari responden, hal tersebut menunjukkan bahwa hasil penelitian pada indikator kehadiran ada pada tingkat penilaian sangat baik dengan hasil $92,8 \%$.

Ketaatan pada peraturan kerja Pegawai yang senangtiasa taat dengan peraturan kerja tidak akan melalaikan prosedur kerja dan selalu mengikuti pedoman yang telah ditetapkan oleh organisasi.. Ketaatan pada peraturan kerja dalam penelitian ini adalah bagian dari indikator dalam variabel Kedisiplinan Pegawai di Kantor Dinas Kependudukan dan pencatatan Sipil Kabupaten Takalar. Maka untuk mengetahui indikator ketaatan pada peraturan kerja diukur melalui sub indikator dalam lima pernyataan. Berdasarkan data tabel diatas maka indikator ketaatan pada peraturan kerja dengan lima item pernyataan penilaian rata-rata dari 50 responden yaitu $28,8 \%$ responden yang memberikan penilaian sangat setuju (SS), $61,6 \%$ responden yang memberikan penilaian setuju (S), 9,2\% responden yang memberikan penilaian kurang setuju (KS), $0,4 \%$ responden yang memberikan penilaian tidak setuju (TS), dan $0 \%$ responden yang memberikan penilaian sangat tidak setuju (STS) terhadap indikator ketaatan pada peraturan kerja divariabel $\mathrm{Y}$ (Kedisiplinan Pegawai).

Hasil analisis deskriptif tentang indikator ketaatan pada peraturan kerja dapat dilihat bahwa penilaian rata-rata responden paling tinggi adalah $61,6 \%$ responden memberikan penilaian setuju, sedangkan penilaian rata-rata responden paling rendah adalah $0,4 \%$ responden memberikan penilaian tidak setuju. Indikator ketaatan pada peraturan kerja di Kantor Dinas Kependudukan dan Pencatatan Sipil Kabupaten Takalar menunjukkan bahwa memiliki penilaian sangat baik yaitu sebesar 90,4\% responden, penilaian tersebut diperoleh dari hasil analisis indikator ketaatan pada peraturan kerja sebesar 61,6 \% responden setuju dijumlah dengan $28,8 \%$ responden sangat setuju. Namun dengan begitu masih ada beberapa responden yang memberikan penilaian tidak baik sebesar $9,6 \%$ responden yang diperoleh dari penilaian sebesar 9,2\% responden ragu-ragu dijumlah dengan $0,4 \%$ responden tidak setuju.

Hasil penelitian merupakan hasil observasi peneliti dilapangan, bahwa kedisiplinan pegawai di Kantor Dinas Kependudukan dan Pencatatan Sipil Kabupaten Takalar pada indikator ketaatan pada peraturan kerja yaitu dengan melihat aktivitas yang dilakukan akan diselesaikan dengan baik, sehingga akan memberikan keuntungan pada instansi dan mendapatkan tanggapan yang sangat baik dari responden, hal tersebut menunjukkan bahwa hasil penelitian pada indikator kehadiran ada pada tingkat penilaian sangat baik dengan hasil $90,4 \%$ tingkat penilaian tersebut dikatakan sangat baik.

Ketaatan pada standar kerja Hal ini dapat diketahui dengan melihat besarnya tanggung jawab seorang pegawai terhadap tugas-tugas yang diberikan kepadanya.Ketaatan pada standar kerja dalam penelitian ini adalah bagian dari indikator dalam variabel Kedisiplinan Pegawai di Kantor Dinas Kependudukan dan pencatatan Sipil Kabupaten Takalar. Maka untuk mengetahui indikator kehadiran diukur melalui sub indikator dalam lima pernyataan. Berdasarkan hasil deskriptif diatas maka indikator ketaatan pada standar kerja dengan lima item pernyataan penilaian rata-rata dari 50 responden yaitu $33,2 \%$ responden yang memberikan penilaian sangat setuju (SS), $64,4 \%$ responden yang memberikan penilaian setuju (S), 2,4\% responden yang memberikan penilaian kurang setuju (KS), 0\% responden yang memberikan penilaian tidak setuju (TS), dan $0 \%$ responden yang memberikan penilaian sangat tidak setuju (STS) terhadap indikator ketaatan pada standar kerja divariabel $\mathrm{Y}$ (Kedisiplinan Pegawai). Hasil analisis deskriptif tentang indikator ketaatan pada standar kerja dapat dilihat bahwa penilaian rata-rata responden paling tinggi adalah $64,4 \%$ responden memberikan penilaian setuju, sedangkan penilaian rata-rata responden paling rendah adalah 2,4\% responden memberikan penilaian tidak setuju. Indikator ketaatan pada standar kerja di Kantor Dinas Kependudukan dan Pencatatan Sipil Kabupaten Takalar menunjukkan bahwa memiliki penilaian sangat baik yaitu sebesar 97,6\% responden, penilaian tersebut diperoleh dari hasil analisis indikator ketaatan pada standar kerja sebesar 64,4\% responden setuju dijumlah dengan $33,2 \%$ responden sangat setuju. Namun dengan begitu masih ada beberapa responden yang memberikan penilaian tidak baik sebesar $2,4 \%$ responden 
yang diperoleh dari penilaian ragu-ragu. Hasil penelitian diatas merupakan hasil observasi peneliti dilapangan, bahwa kedisiplinan pegawai di Kantor Dinas Kependudukan dan Pencatatan Sipil Kabupaten Takalar pada indikator ketaatan pada standar kerja yaitu dengan melihat aktivitas yang dilakukan akan diselesaikan dengan baik, sehingga akan memberikan keuntungan pada instansi dan mendapatkan tanggapan yang sangat baik dari responden, hal tersebut menunjukkan bahwa hasil penelitian pada indikator kehadiran ada pada tingkat penilaian sangat baik dengan hasil $97,6 \%$.

Tingkat Kewaspadaan Tinggi dalam penelitian ini adalah bagian dari indikator dalam variabel Kedisiplinan Pegawai di Kantor Dinas Kependudukan dan pencatatan Sipil Kabupaten Takalar. Maka untuk mengetahui indikator tingkat kewaspadaan tinggi diukur melalui sub indikator dalam lima pernyataan. Berdasarkan data tabel diatas maka indikator Tingkat Kewaspadaan Tinggidengan lima item pernyataan penilaian rata-rata dari 50 responden yaitu $34,4 \%$ responden yang memberikan penilaian sangat setuju (SS), 60\% responden yang memberikan penilaian setuju (S), 5,6\% responden yang memberikan penilaian kurang setuju (KS), $0 \%$ responden yang memberikan penilaian tidak setuju (TS), dan $0 \%$ responden yang memberikan penilaian sangat tidak setuju (STS) terhadap indikator Tingkat Kewaspadaan Tinggi divariabel Y (Kedisiplinan Pegawai). Indikator tingkat kewaspadaan tinggi di Kantor Dinas Kependudukan dan Pencatatan Sipil Kabupaten Takalar menunjukkan bahwa memiliki penilaian sangat baik yaitu sebesar $94,4 \%$ responden, penilaian tersebut diperoleh dari hasil analisis indikator tingkat kewaspadaan tinggi sebesar $60 \%$ responden setuju dijumlah dengan $34,4 \%$ responden sangat setuju. Namun dengan begitu masih ada beberapa responden yang memberikan penilaian tidak baik sebesar $5,6 \%$ responden yang diperoleh dari penilaian ragu-ragu.

Bekerja etis Biasanya beberapa pegawai melakukan tindakan indisipliner dengan cara melakukan tindakan yang kurang sopan, sehingga bekerja etis dijadikan sebagai salah satu wujud dari disiplin kerja..Bekerja Etis dalam penelitian ini adalah bagian dari indikator dalam variabel Kedisiplinan Pegawai di Kantor Dinas Kependudukan dan pencatatan Sipil Kabupaten Takalar. Maka untuk mengetahui indikator Bekerja Etis diukur melalui sub indikator dalam lima pernyataan. Berdasarkan deskriptif maka indikator Bekerja Etis dengan lima item pernyataan penilaian rata-rata dari 50 responden yaitu $33,2 \%$ responden yang memberikan penilaian sangat setuju (SS), 64\% responden yang memberikan penilaian setuju (S), 2,8\% responden yang memberikan penilaian kurang setuju (KS), $0 \%$ responden yang memberikan penilaian tidak setuju (TS), dan $0 \%$ responden yang memberikan penilaian sangat tidak setuju (STS) terhadap indikator Bekerja Etis divariabel Y (Kedisiplinan Pegawai). Hasil analisis deskriptif tentang indikator Bekerja Etis dapat dilihat bahwa penilaian rata-rata responden paling tinggi adalah $64 \%$ responden memberikan penilaian setuju. Indikator Bekerja Etis di Kantor Dinas Kependudukan dan Pencatatan Sipil Kabupaten Takalar menunjukkan bahwa memiliki penilaian sangat baik yaitu sebesar 97,2\% responden, penilaian tersebut diperoleh dari hasil analisis indikator Bekerja Etis sebesar $64 \%$ responden setuju dijumlah dengan $33,2 \%$ responden sangat setuju. Namun dengan begitu masih ada beberapa responden yang memberikan penilaian tidak baik sebesar 2,8\% responden yang diperoleh dari penilaian ragu-ragu.

Berdasarkan perhitungan dari analisis data dari kelima indikator variabel Y "Kedisiplinan Pegawai" Dari hasil pelaksanaan kuesioner kedisiplinan pegawai yaitu sebesar $85,50 \%$ menunjukkan bahwa kedisiplinan pegawai berada pada penilaian sangat baik. Dapat disimpulkan bahwa gaya kepemimpinan transformasional memberikan pengaruh yang sangat baik terhadap kedisiplinan yang dilakukan pegawai semakin baik pula hasil kinerja yang didapatkan.

Pengaruh Gaya Kepemimpinan Transformasional Terhadap Kedisiplinan Pegawai di Kantor Dinas Kependudukan dan Pencatatan Sipil Kabupaten Takalar dapat dilihat pada tabel dibawah ini :

Berdasarkan tabel diatas dapat disimpulkan bahwa pengaruh variabel gaya kepemimpinan transformasional (X) terhadap variabel kedisiplinan pegawai (Y) dapat ditentukan dengan menggunakan analis regresi sederhana. Regresi sederhana dapat dilakukan 
untuk menganalisis pengaruh antara variabel independen yaitu gaya kepemimpinan transformasional (X) terhadap varibael dependen yaitu kedisiplinan pegawai $(Y)$ di Kantor Dinas Kependudukan dan Pencatatan Sipil Kabupaten Takalar. Pengambilan keputusan dalam uji regresi linear sederhana memicu pada dua hal yakni : (a) Jika nilai signifikan lebih kecil $<0,05$ artinya variabel berpengaruh terhadap variabel, maka $\mathrm{Ha}$ diterima dan Ho ditolak. (b) Jika nilai signifikan lebih besar > 0,05 artinya variabel $\mathrm{X}$ tidak berpengaruh terhadap variabel $\mathrm{Y}$, maka Ha ditolak dan Ho diterima.

Berdasarkan hasil analisis data statistik tabel Anova digunakan untuk menentukan model persamaan regresi sederhana yang diketahui bahwa nilai $F_{\text {hitung }}=52,784$ dengan tingkat signifikan 0,000 lebih kecil dari $<0,05$ maka variabel gaya kepemimpinan transformasional $(\mathrm{X})$ berpengaruh terhadap variabel kedisiplinan pegawai (Y). Adapun rumus model persamaan regresi sederhana yang digunakan dalam menentukan besar pengaruh variabel $\mathrm{X}$ terhadap variabel $\mathrm{Y}$ dalam penelitian ini sebagai berikut :

$\mathrm{Y}=\mathrm{a}+\mathrm{bX}$

$\mathrm{Y}=31,592+0,904(0)$

$\mathrm{Y}=31,592$

Berdasarkan persamaan regresi diatas maka dapat disimpulkan bahwa nilai kofisien regresi (b) nilainya sebesar 0,904 yang menyatakan bahwa jika gaya kepemimpinan transformasional $(\mathrm{X})$ niainya 0 maka hasil kedisiplinan pegawai (Y) nilainya positif 31,592. Setiap penambahan $1 \%$ nilai gaya kepemimpinan transformasional maka nilai kedisiplinan pegawai semakin bertambah sebsar 0,904 koefisien regresi tersebut positif, sehingga dapat dikatakan berpengaruh antara variabel gaya kepemimpinan transformasional (X) terhadap variabel kedisiplinan pegawai (Y) dengan nilai sebesar 31,592. Apabila ditingkatkan nilai gayakepemimpinan transformasional (X) maka kedisiplinan pegawai (Y) akan semakin meningkat berarti ada pengaruh antara gaya kepemimpinan transformasional terhadap kedisiplinan pegawai di Kantor Dinas Kependudukan dan Pencatatan Sipil Kabupaten Takalar.

\begin{tabular}{|c|c|c|c|c|}
\hline \multicolumn{5}{|c|}{ Model Summary } \\
\hline Model & $\mathrm{R}$ & $\begin{array}{c}\mathrm{R} \\
\text { Square }\end{array}$ & $\begin{array}{l}\text { Adjusted } \\
\text { R Square }\end{array}$ & $\begin{array}{l}\text { Std. Error } \\
\text { of the } \\
\text { Estimate }\end{array}$ \\
\hline
\end{tabular}

\begin{tabular}{|c|c|c|c|c|}
\hline &, $724^{\mathrm{a}}$ &, 524 & .514 & 5,367 \\
\hline
\end{tabular}

\begin{tabular}{|c|c|c|c|c|c|c|}
\hline \multicolumn{7}{|c|}{ Anova $^{a}$} \\
\hline & Model & $\begin{array}{l}\text { Sum of } \\
\text { Squares }\end{array}$ & Df & $\begin{array}{l}\text { Mean } \\
\text { Square }\end{array}$ & $F$ & Sig. \\
\hline \multirow{3}{*}{1} & Regression & 1520,549 & 1 & 1520,549 & 52,784 &, $000^{\mathrm{b}}$ \\
\hline & Residual & 1382,731 & 48 & 28,807 & & \\
\hline & Total & 2903,280 & 49 & & & \\
\hline
\end{tabular}

a. Dependent Variable: Kedisiplinan_Pegawai

b. Predictors: (Constant), Gaya_Kepemimpinan Transformasional

Coefficientsa

\begin{tabular}{cccccc}
\hline Model & $\begin{array}{c}\text { Unstandardi } \\
\text { zed } \\
\text { Coefficients }\end{array}$ & $\begin{array}{c}\text { Standar } \\
\text { dized } \\
\text { Coeffici } \\
\text { ents }\end{array}$ & t & $\begin{array}{c}. S i \\
\mathrm{~g}\end{array}$ \\
\hline & $\mathrm{B}$ & $\begin{array}{c}\text { Std. } \\
\text { Erro } \\
\mathrm{r}\end{array}$ & Beta & & \\
\hline & & & & \\
\hline (Constant) & 31,5 & 10,3 & & 3,0 &, 0 \\
& 92 & 90 & & 41 & 04 \\
\hline $\begin{array}{c}\text { Gaya_Kepemi } \\
\text { mpinan } \\
\begin{array}{c}\text { Transformasio } \\
\text { nal }\end{array}\end{array}$ &, 904 &, 124 &, 724 & 7,2 &, 0 \\
& & & & 65 & 00 \\
\hline
\end{tabular}

a. Dependent Variable: Kedisiplinan_Pegawai

Berdasarkan hasil analisis data statistik tabel 4.22 model summary menjelaskan besarnya nilai korelasi atau hubungan (R) sebesar 0,724 dari output tersebut diperoleh dari koefisien determinasi ( R Square) 0,524 atau $52,4 \%$ yang mengandung arti bahwa pengaruh gaya kepemimpinan transformasional (X) terhadap kedisiplinan pegawai (Y) di Kantor Dinas Kependudukan dan Pencatatan Sipil Kabupaten Takalar sebesar $52,4 \%$ sedangkan sisanya 0,476 atau $47,6 \%$ yang diperoleh dari $100 \%-47,6 \%=$ $52,4 \%$ yang merupakan variabel yang diteliti sedangkan $47,6 \%$ variabel lain yang tiak diteliti.

\section{KESIMPULAN}

Berdasarkan hasil penelitian yang dilakukan tentang pengaruh gaya kepemimpinan transformasional terhadap kedisiplinan pegawai di Kantor Dinas Kependudukan dan Pencatatan Sipil Kabupaten Takalar, maka dapat ditarik kesimpulan sebagai berikut :

Gaya kepemimpinan transformasional di Kantor Dinas Kependudukan dan Pencatatan Sipil Kabupaten Takalar sudah diterapkan dengan sangat baik, hal sesuai dengan jawaban 
responden dari kuesioner yang dibagikan peneliti serta hasil perhitungan pada tabel 4.32 yang menunjukkan bahwa gaya kepemimpinan transformasional yang dijalankan pimpinan di Kantor Dinas Kependudukan dan Pencatatan Sipil Kabupaten Takalar berada dalam kategori sangat baik yaitu sebesar $83,26 \%$ hasil yang diperoleh dari perhitungan rata-rata kuesioner peneliti.

Berdasarkan hasil analisis statistic tabel 4.38model summary, menjelaskan besarnya nilai korelasi atau hubungan (R) sebesar 0,724 . Dari besar pengaruh variabel $\mathrm{X}$ "Gaya Kepemimpinan Transformasional " terhadap variabel Y "Kedisiplinan Pegawai" ditunjukkan oleh nilai R Square sebesar 0,524 artinya $52,4 \%$ pengaruh variabel gaya kepemimpinan transformasional (X) terhadap variabel kedsiplinan pegawai (Y) di Kantor Dinas Kependudukan dan Pencatatan Sipil Kabupaten Takalar.Berdasarkan hasil pengujian hipotesis yaitu dengan mengkonsultasikan nilai t hitung dengan nilai $r$ tabel, dan melakukan uji $\mathrm{t}$ yang diketahui bahwa t hitung > t tabel $(31,592>2,008)$ atau signifikan (Sig) sebesar 0,000 lebih kecil dari $<0,05$ sehingga berarti $\mathrm{H}_{a}$ diterima dan $\mathrm{H}_{0}$ ditolak. Hal ini berarti gaya kepemimpinan berpengaruh terhadap kedisiplinan pegawai di Kantor Dinas Kependudukan dan Pencatatan Sipil Kabupaten Takalar.

\section{REFERENSI}

Ali, Eko Maulana. 2013. Kepemimpinan Integratif Dalam Konteks Good Governance.PT. Multicerdas Publising.

Ali, Eko Maulana. 2012. Kepemimpinan Dalam Birokrasi Pemerintahan. PT. Multicerdas Publishing.

Ananto Reza, 2014. Analisis Pengaruh Gaya Kepemimpinan, Motivasi Dan Disiplin Kerja Terhadap Kinerja Pegawai (Studi Empiris Pada PT DHL Global Forwarding Semarang Branch). Skripsi: Fakultas Ekonomika Dan Bisnis Universitas Diponegoro Semarang.

Northouse, Peter G. 2013. Kepemimpinan : Teori dan Praktik, Edisi Keenam. Jakarta Barat: PT. Indeks.

Purnamasari, Widi. 2015. Pengaruh Disiplin Kerja, Komitmen Organisasi, Dan Lingkungan Kerja Terhadap Kinerja Pegawai Negeri Sipil Balai Besar
Wilayah Sungai Pemali-Juana. Jurnal Manajemen UDINUS

Rivai, Veithzal \& Deddy Mulyadi. 2011. Kepemimpinan dan Perilaku Organisasi. Jakarta: PT. Raja Grafindo Persada.

Sugiono, 2014. Metode Penelitian Pendidikan Kuantitatif, Kualitatif, dan $R \& D$, Bandung. Alfabeta.

Setiawan, Bahar Agus. 2013. TransformasionalLeadership: Ilustrasi dibidang Organisasi Pendidikan. Jakarta: Rajawali.

Tampi, Johannes Bryan. 2014. Pengaruh Gaya Kepemimpinan Dan Motivasi Terhadap Kinerja Kariawan Pada PT. Bank Negara Indonesia. Jurnal Acta Diurnal, Volume 3, No 4.

Yulk, Gery. 2009. Kepemimpinan Dalam Organisasi. Jakarta: PT. Indeks.

Peraturan Pemerintah Republik Indonesia Udang-Undang Nomor 53 Tahun 2010 Tentang Disiplin Pegawai Negeri Sipil 